different, but the bricks are similar. The association of enzyme system with various membranous components of the cell is well established, and it may be that mutations and adaptations in response to unusual environments are accompanied by ultrastructural changes. If so, microorganisms would seem to be the best experimental material for this type of investigation. One must agreo wholeheartedly with Dubos's statement: "The biophysical and biochemical unity of life is certainly one of the largest contributions of modern science to philosophical thought".

In so short a book it is inevitable that some topies are discussed inadequately. There is an occasional loose statement, as, for example, in discussing Pasteur's work: ". . . he found that one solution deviated polarized light to the right and the other to the left", but one sympathizes with the difficulty of trying to explain polarized light to a general audienco. The section on antibiotics is very brief, and the birth dates of Florey and Chain are unfortunately interchanged. It is perhaps a pity that space could not be found for the contributions of John Tyndall, himself closely associated with the Royal Institution. His Essays on the Floating Matter of the Air published in 1881 are an excellent example of clear thinking and he must surely rank among the great pioneers of biophysies and microbiology. Not only did he observe the antagonism between some moulds and bacteria but he stressed the importance of species differences. In describing the contamination of bactorial cultures by Penicillia he writes: "In every case where the mould was thick and coherent the Bacteria died, or became dormant, and fell to the bottom as a sediment. . . The turnip-infusion, after developing in the first instance its myriadfold Bacterial life, frequently contracts mould, which stifles the Bacteria and clears the liquid all the way between the sediment and the scum. . . . The Bacteria which manufacture a green pigment appear to be uniformly victorious in their fight with the Penicillium". So near, yet sixty years too far. Dubos's book makes us wonder what great discoveries are being missed to-day.

R. BARER

\section{ESSAYS OF GEORGE SARTON}

Sarton on the History of Science

Essays by George Sarton. Selected and edited by Dorothy Stimson. Pp. xvi 383 (Cambridge, Mass.: Harvard University Press; London: Oxford University Press, 1962.) 80s. not.

GEORGE SARTON, first professor of the history of $G$ science at Harvard, died in 1956 . For many years he had been one of the leading authorities on his subject, and the editor of this collection of his essays claims that for forty years his name was "practically synonymous with the history of science". So far as the United States is concerned, this statement is unlikely to be challenged.

Sarton was a man of great erudition, an exact and exacting scholar, to which accomplishments he coupled immense energy. $\mathrm{H}_{e}$ is probably best known as the founder of the international journal, Isis, devoted to the history of science, which he edited for some forty years, and to which he regularly contributed a valuable oritical bibliography on the history of science and related subjects. $\mathrm{He}$ was, however, a prolific writer and. apart from his editorial work, was the author of a number of books and of numerous essays and articles on various aspects of his subject. Before his death, Sarton drew up a list of those among the latter that he considered worth re-publishing. All but three of the twenty-three articles included in Sarton on the History of Science were included in this list. Thirteen were published originally in Isis. 'The remainder appeared in a variety of publications for the most part not easily accessible. The selection has been made, and the articles edited, at the request of Sarton's literary executors, by Prof. Dorothy Stimson, whose name may be familiar to British readers as the author of Scientists and Amateurs, a short history of the Royal Society.

The essays have been arranged in three groups to illustrate the varying aspects of Sarton's work. Those in the first group omphasize his activities as propagandist for the study of the history of science, and among them is the last important article he wrote, an essay on the history of science contributed to the Encyclopedia Americana in 1956. Those in the second group illustrate his work as a historian of science proper. They are mainly biographical, and the subjects chosen range from an essay on Avicenna to one on the work of the twentieth-century scientist, H. C. J. Mosely. A long article on Leonardo da Vinei, not hithorto published in full, is included. The third group has been selected to illustrate Sarton's methods and procedure as a writer and editor. In this section there are articlos on such diverse subjects as English as an international language, notes on reviewing learned books, the study of early scientific text-books, and the history of twentieth-century science.

Apart from the value of some of these essays as source material, for example, that on the sixteenth-century Belgian scientist Simon Stevin, this book forms a readable introduction to Sarton's work as a whole. As such it ought to be welcomed by British students of the history of science to whom his contributions to the subject are possibly not as well or, at least, as fully known as they deserve to be.

\section{HOMAGE TO GEORGE PÓLYA}

Studies in Mathematical Analysis and Related Topics Essays in Honor of George Pólya. (Stanford Studies in Mathematics and Statistics, No. 4.) Edited by Gabor Szegö, Charles Loewner, Stefan Bergman, Menahem Max Schiffer, Jerzy Neyman, David Gilbarg, Herbert Solomon. Pp. xxi +447. (London: Oxford University Press, 1962.) $80 s$.

DAPERS from sixty notable mathematicians testify to P the respect and, more, to the affection in which Prof. Pólya is held by the contemporary mathematical world. His high professional competence is shown by an output of more than 200 research memoirs; the lucidity of his exposition is known to his readers as well as to those fortunate enough to have heard him lecture. But this is not all; every teacher of mathematics, every young research worker in the field of analysis, can find inspiration and assistance in those of his books in which he has dealt, explicitly or implicitly, with the modes of mathematical discovery and creation. In the middle 1920's, Pólya (in collaboration with Szegö), in the two volumes of Aufgaben und Lehrsätze aus der Analysis, offered the young analyst a remarkable opportunity of sharpening the tools of his trade by studying the grouped sets of problems (with solutions) on most topics in analysis from the fundamentals of limit theory to complex variable and the analytic theory of numbers; here the novice could see how general theorems could be applied and sharpened in applications to special problems.

After the Second World War, Pólya began writing on the motivation and presentation of mathematical discovery. He emphasized the part played by intuition (perhaps better described as controlled guess-work), a part as important as that played by strict logical inference. Great mathematicians such as Gauss have delighted in publishing their discoveries in concise synthetic form; in recent years, research memoirs have been compressed to extremos in response to editorial demands for economy of space. The young student may marvel at the results, but he will not easily see how they were arrived at. In his books, How to Solve It (Princeton, 1946) and Induction and Analogy in Mathematics (Oxford, 1954), Pólya shows by an opulent variety of examples how a mixture of inductive 